1.はじめに

豊羽鉱山は現在、東西 $3 \mathrm{~km}$ 、南北 $2 \mathrm{~km}$ の範囲において、 深度ー100ML〜-450MLの間で採掘及び探鉱を、 それより下部のー600MLまでは探鉱作業を実施してい る。これらの穆行区域全域にわたって初期岩盤温度が非常 に高く鉱体の開発を進めるに当って、高温岩盤内を掘さく しなければならない宿命を背負っている。

現在まで、初期岩盤温度約 $100^{\circ} \mathrm{C}$ 鉱体の採掘を経験し ているが、近年発見され、その開発に着手し始めた信濃鉱 体は、当山の熱源に近いと考えられている南東城に位置し、 最高 $160^{\circ} \mathrm{C}$ 程度の岩盤温度となることが予想され、同時 に、熱水、及び水蒸気の地熱流体が存在する。

ここで、このような作業条件の悪化に対して、いかなる 掘さくを行っているか、また今後、いかなる取り組み方を しようとしているかについて報告する。

2. 高温岩体の掘さくに伴う問題

$2-1$. 切羽温度の上昇

第 1 図に、代表的レベルの地熟温度分布と新規開発予定 鉱体の区域を示す。

初期岩盤温度は試錐の際の測定值より予測したものである

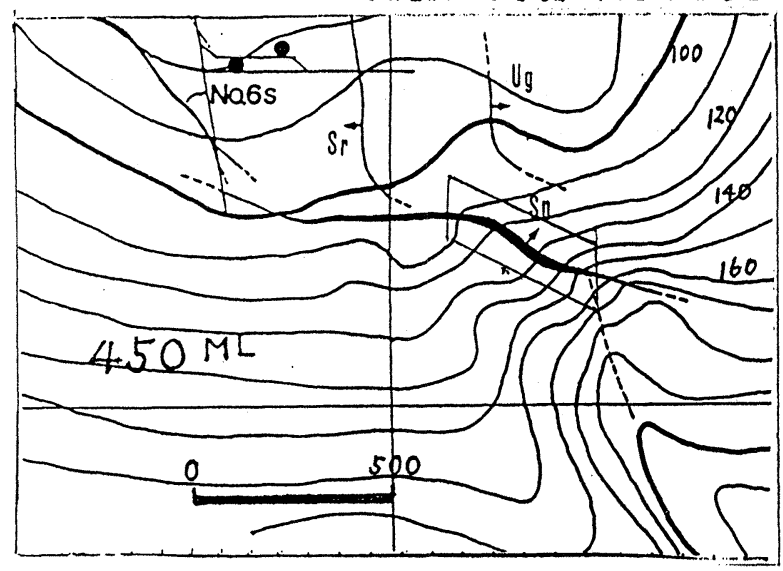

第1図岩盤温度分布図

坑内温度を上昇させる主要因は、地熱、温泉、動力源か らの発熱、鉱石からの酸化熱等である。特に開発当初は、 通気系統が確立されていないので、大量の通気による気流 温度の低下、あるいは坑道譬面の早期冾却は期待出来ない 。従って掘さく時は、(イ)冷水噴霖による冷却、(口)局部 鼠風機による通気という従来通りの方法に頼らさるを得な い。
豊羽鉱山(株) 竹 村

" 坂 井 慎 二



第2 図、岩盤温度と通気量、気流温度の関係

$2-2$. 穿孔、装薬、発破

高温岩盤の掘さくで、最も問題となるのは使用する火藻 類の安全性である。岩盤温度は、急激な上昇あるいは下降 はないので、定期的に装薬孔に留点温度計を㨂入して、岩 盤温度を測定し、使用する爆薬及び雷管を決めている。

地熱流体は、裂濞を充填した鉱脈の存在とほぼ一致して いて、そのため踊押坑道の掘さくが最も環境が覀くなって いる。

踊押坑道穿孔時、部分的なガマに当たり、地熱流体が㴊 出する場合がある。これをそのまま放固しておくと、切羽 温度の上昇、視界性の問題が生じるのでパッカーを孔中に 投入して、ホースで後方に遒く方法を採る。大抵一時的な ものであるが、䒾薬前でも涌出が咸少しない場合、周辺に 別の孔を穿孔し、熱水、蒸気等を排出させる。

銿押坑道での発破において、しばしば、起砕不良となる 揚合があった。この原因を追及した結果、込栓による閉塞 状態で孔中の圧力が上昇し、爆薬の紙包が破れて薬自休が 細分化してしまう事が解り、紙包の気密性及び防水性の強 化を図り、この問題を解決した。

$$
2-3 \text {. 積込 }
$$

ディーゼル駆動の積込機を使用する場合、その排気温度 は $80^{\circ} \mathrm{C} に も 上$ 昇し、切羽温度を更に上昇させる要因とな る。また冷却用水、湧水等が直接機械にかかったり、高温 状沉下の作業のため、故障頻度が高い。

\section{3. 高温岩体の掘さくにおける最近の技術改善} $3-1$. 火薬類

見在掘さく中の切羽での初期岩盤温度は、最高で 120 ${ }^{\circ} \mathrm{C}$ 程度あり、岩盤温度分布図とほぼ合っている。 これに対して、火薬類は、1 $160^{\circ} \mathrm{C} て ゙ 24$ 時間経過しても 起爆することなく、かつその性能が損なわれない事を基淮 に開発されたものである。 
従来使用していたスラリー系爆薬は岩盤温度 $\left(70^{\circ} \mathrm{C}\right.$ 、 $\left.110^{\circ} \mathrm{C} 、 160^{\circ} \mathrm{C}\right)$ により 3 ランクに分けて 3 種類の爆 薬を使用していたが、エマルジョン系酎熱爆薬の開発によ り、7 $0^{\circ} \mathrm{C}$ こえる岩盤に対しては一種類の爆薬で対応で きるようになった。

\begin{tabular}{|c|c|c|}
\hline \multirow[b]{2}{*}{ 岩盤温度 } & \multicolumn{2}{|c|}{ 火 薬 数 } \\
\hline & 雷 管 & 爆 \\
\hline $70^{\circ} \mathrm{C}$ 未満 & 普 通 & $\begin{array}{l}\text { チタマイト } \\
\text { アランドマイト } \\
\text { アンホ (カート、バラ) }\end{array}$ \\
\hline $\begin{array}{l}70^{\circ} \mathrm{C} \text { 以上 } \\
110^{\circ} \mathrm{C} \text { 末満 }\end{array}$ & 耐 熱 & \\
\hline $\begin{array}{l}110^{\circ} \mathrm{C} \text { 以上 } \\
160^{\circ} \mathrm{C} \text { 未満 }\end{array}$ & 超酎熱 & 酎熱チタマイト \\
\hline
\end{tabular}

第 1 表 岩紫温度と使用火薬類との関係

\begin{tabular}{|c|c|c|}
\hline & & $\begin{array}{l}\text { 酎熱チタマイト } \\
\left(70^{\circ} \mathrm{C} \sim 160^{\circ} \mathrm{C}\right)\end{array}$ \\
\hline \multirow{4}{*}{\multicolumn{2}{|c|}{ 配 合 組 成 }} & AN $\quad 70 \sim 75 \%$ \\
\hline & & $3 \sim 7 \%$ \\
\hline & & 水. $\mathrm{GMB} \quad 10 \sim 14 \%$ \\
\hline & & $7 \sim 13 \%$ \\
\hline \multirow{5}{*}{ 性 } & 状 & 膠質・紙包装 \\
\hline & 雱水・吸湿性 & 優 秀 \\
\hline & 㑂比重 $(\mathrm{g} / \mathrm{cc})$ & $1.25 \sim 1.35$ \\
\hline & 爆速 $(\mathrm{m} / \mathrm{s})$ JIS法 & $5,200 \sim 5,700$ \\
\hline & 落书感度 JIS法 & 8 級 $(200 \mathrm{~cm}$ 以上 $)$ \\
\hline \multirow[t]{3}{*}{ 能 } & 発火点 $\left({ }^{\circ} \mathrm{C}\right)$ & \multirow{2}{*}{450} \\
\hline & クリップ式 & \\
\hline & 耐 熱 性 & $\begin{array}{l}160^{\circ} \mathrm{C} 24 \mathrm{~h} \mathrm{r} \text { 以上 } \\
\text { 分解せず }\end{array}$ \\
\hline
\end{tabular}

第 2 表 酎熱爆薬性能表

将来岩盤温度が $160^{\circ} \mathrm{C}$ 以上になることも、充分予想さ れ、 $180^{\circ} \mathrm{C}$ まで条件に耐え得る火薬類の早期開発を目 ざしている。雷管については、大巾なコストの上昇なしで ほぼ目途がついている。

\section{$3-2$. 使用機械}

第 3 図に、前述の高温岩体域に賦存する信莀銿のサブレ ベル探掘の開坑模式図を示す。

従来採掘用長孔さく岩機の関係で、3 中段方式を採用し ていたが、ダウンザホールドリルジャンボの導入により、 長孔穿孔が可能となり、2中段方式に変更して採掘淮備期 間及びコストの削減を図る。

開坑に当っての機械の選択については、(イ)坑道の仕様 に適合するもの、(口)大型化、連続作業等により工程の上 昇がはかれるもの、(八)切羽の環境を悪化させないもの、 等を考虑した。

機械の故障対策としては、（イ）制御盤等防水性の強化

（ロ）オイルクーラーの容量増、（八）錆に強い敍装、

（二）電気端子類の防錆処理、（ホ）酎熱シール類の使用 等を実施している。

特に、積込機の電動化による効果は、このような環境下 においては、非常に大きなものとなっている。

\begin{tabular}{|c|c|c|c|c|c|}
\hline \multirow[b]{2}{*}{ 坑道名 } & \multirow{2}{*}{$\begin{array}{l}\text { 加 背 } \\
(\mathrm{W} \times \mathrm{H})\end{array}$} & \multicolumn{2}{|l|}{ 穿 孔 機 械 } & \multicolumn{2}{|c|}{ 積 込 機 械 } \\
\hline & & $x-カ-$ & 動力 & $x-カ-$ & 動力 \\
\hline 下部錚押 & $3.0 \times 2.5$ & $\begin{array}{l}\text { *タイヤ式ジャンボ } \\
\text { PDー90搭載 } \\
\text { (古河) }\end{array}$ & 压気 & $\begin{array}{l}\text { *シャフロータ } \\
\text { KL } 7 \\
\text { (コトブキ技研) }\end{array}$ & 要気 \\
\hline 上部頝押 & $3.0 \times 2.5$ & $\begin{array}{l}\text { *タイヤ式ジャンボ } \\
\text { P D -90搭载 } \\
\text { (古河) }\end{array}$ & 压気 & $\begin{array}{l}2 y d^{3} \text { LHD } \\
922 \mathrm{E} \\
\text { (三井アイムコ) }\end{array}$ & 電気 \\
\hline ランプ & $4.0 \times 3.0$ & $\begin{array}{c}\text { * 油圧ジャンボ } \\
\text { H L-438搭载 } \\
\text { (タムロック) }\end{array}$ & 電気 & $5 y d^{3}$ LHD & 電気 \\
\hline $\begin{array}{c}\text { 積込 } \\
\text { ドローポイント } \\
\text { 立入 }\end{array}$ & $4.0 \times 3.0$ & 同上（兼用） & & $\begin{array}{r}\text { *サイドダンプ } \\
\text { ローダ } \\
\text { ME 615 } \\
\text { (三井アイムコ) }\end{array}$ & 電気 \\
\hline 第 1 中段 & $3.0 \times 2.5$ & 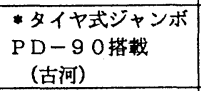 & 区気 & $\begin{array}{l}2 \mathrm{yd}^{3} \mathrm{LHD} \\
922 \mathrm{E} \\
\text { (三井アイムコ) }\end{array}$ & 電気 \\
\hline $\begin{array}{l}\text { 下部主要 } \\
\text { 迎搬坑道 }\end{array}$ & $3.0 \times 2.5$ & $\begin{array}{c}\text { * 油圧ジャンボ } \\
\text { H L - 4 38 8搭載 } \\
\text { (タムロック) }\end{array}$ & 電気 & $\begin{array}{l}\text { *シャフロータ } \\
\text { KL } 7 \\
\text { (コトフキ技研) }\end{array}$ & 電気 \\
\hline スロット立坑他 & $800 \mathrm{~mm} \phi$ & $\begin{array}{l}\text { *レイスボーラー } \\
\text { BM-40 } \\
\text { (鉱研) }\end{array}$ & 電気 & & \\
\hline 集粎坑井 & $1,150 \mathrm{~mm} \phi$ & $\begin{array}{l}\text { *レイスボーラー } \\
\mathrm{BM}-100 \\
\text { (鉱研) }\end{array}$ & 電気 & & \\
\hline 採 掘 & & \begin{tabular}{|c|} 
*ダウンザホール \\
$\quad$ ドリM \\
CMM-2 \\
(インカーソルランド)
\end{tabular} & E気 & & \\
\hline
\end{tabular}

第 3 表 使用機械一覧

*は現在稼行中のものである。

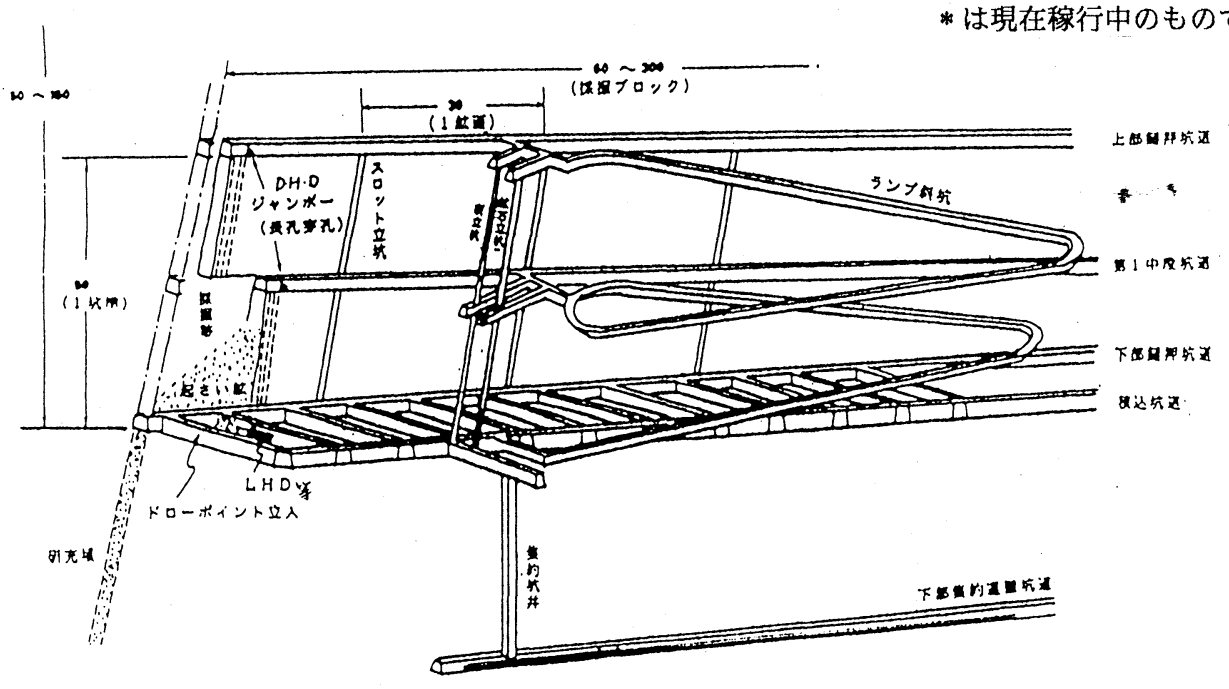

第3図坑道模式図

資源・素材学会誌 105 （1989） No.5 
$3-3$. 環境改善

$3-3-1$, 冷却

泠水を切羽に直接噴衃させる方式は、最も効果が大きく

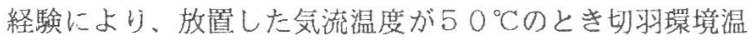
度を10〜15 $5^{\circ} \mathrm{C}$ 低下させることが出米る。また用水管に 法、不然性硬質ポリウレタン保泠材(パイカ)を巻き、送水 中の冷水の温度上昇を防ぐ方法も踏襲している。この他辰 距離の坑道を通ってきた結果、人気自休の温度も上昇して いるので、坑道の各所にもスプレーによる散水を行い冷却 している。これにより、温度の低下のみでなく除じん効果 も大きい。夏期には、ディーゼル式自家発電機の廃熱を利 用した吸収冷凍機を連転して冷却水自休の温度を下げてい る。

\begin{tabular}{|c|l|}
\hline 冷 凍能力 & 300 冷涷卜ン \\
\hline 冷水入口温度 & $15 \sim 10^{\circ} \mathrm{C}$ \\
\hline 出口温度 & $10 \sim 55^{\circ} \mathrm{C}$ \\
\hline 流 量 & $3 \mathrm{~m}^{3} /$ 分 \\
\hline
\end{tabular}

第 4 表 吸収冷凍機仕様

局部扇風機による強制通気は、従来の $15 \mathrm{KW}$ と 560 mm $\phi$ ナイロン風管の組み合せから、1 $5 \mathrm{KW} \times 2$ 台コント

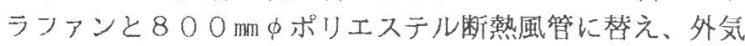
との熱交換を少くして送風することにより入気温度の上昇 を大巾に抑えることが出来るようになった。(5〜1 $\left.0^{\circ} \mathrm{C}\right)$

また、風管途中にフィンクーラーを設置し、より入気温 度を下げる方法も採っている。

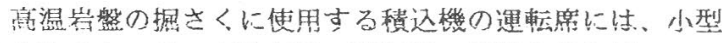
の水冷式クーラーを取付け、運転具の環境改善を図ってい る。

$3-3-2$ 。先進ボーリングによる地熱流体の排出

地熱流休に関しては、今後南東部への開坑が進むに連れ 增えていく傾向にある。铝ってなるべく早く、下盤坑道を 先行させ、地熱流休を先進ボーリング等により排出するこ とにより地下水位を下げて行く事が重要である。この流休 の空気中への放熟は、涌出のない岩盤放熱の数倍にも達し、 このような状態での切羽冷却は困難である。配管によって 熱水はポンプを介して、バックまで尊き、その他の気体は ブロアにより排気孔へ排出している。

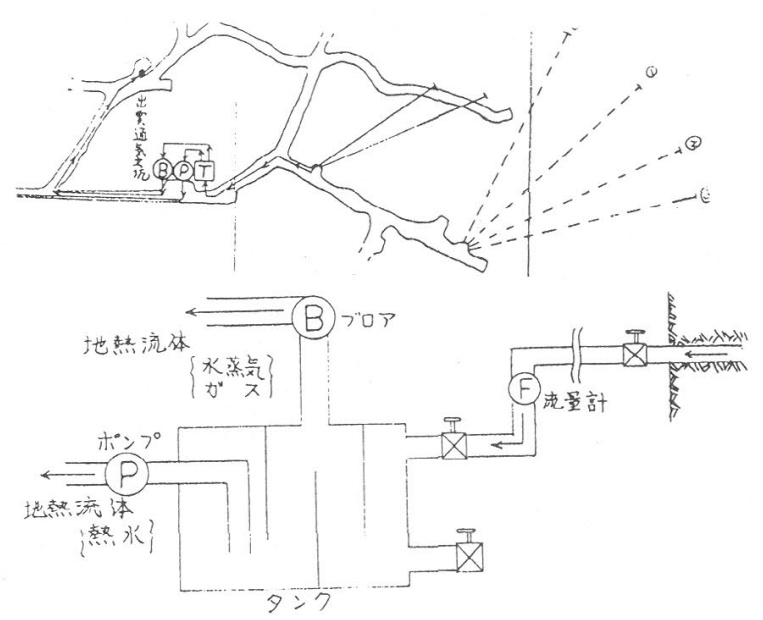

第4 図地髙流体の排出

現在流量計を取り付けて、排出量及びその変化のデータ を収集中である。

$356\langle 12\rangle$
$3-3-3$. 断熱材吹付ライニングの開発

断熱材として、発泡スチロール（製品名はサンド）と接 着剤の役目をする無機質の吹付材（製品名はハイデンパッ ク）を、容積比約 $10 ： 1$ に混合したものを使用した。

吹付け方法としては、タンク容量 40 ～の専用吹付機に 混合物を入れ、空気圧的 $2 \mathrm{~kg} / \mathrm{cm}^{3} に よ る$ 乾式法で、先端， ズルロ元で水と混和した。吹付け厚さは、 $3 \mathrm{~cm}$ 目安とし 約 $30 \mathrm{~m}$ 間実施した。

第 5 表に、吹付前と吹付後の測定結果を示す。

\begin{tabular}{|c|c|c|c|c|c|c|}
\hline \multirow{4}{*}{$\begin{array}{c}\text { 入口 } \\
\text { からの } \\
\text { 距離 } \\
(\mathrm{m})\end{array}$} & \multicolumn{3}{|c|}{ 吹 付 前 } & \multicolumn{3}{|c|}{ 吹 付 後 } \\
\hline & \multirow{3}{*}{$\begin{array}{l}\text { 岩瞥 } \\
\text { 表面 } \\
\text { 温度 } \\
\left({ }^{\circ} \mathrm{C}\right)\end{array}$} & \multicolumn{2}{|c|}{ 気 流 } & \multirow{3}{*}{$\begin{array}{l}\text { 岩盤 } \\
\text { 表面 } \\
\text { 洫度 } \\
\left({ }^{\circ} \mathrm{C}\right)\end{array}$} & \multicolumn{2}{|c|}{ 気 流 } \\
\hline & & 温度 & 湿度 & & 温度 & 湿度 \\
\hline & & $\left({ }^{\circ} \mathrm{C}\right)$ & $(\%)$ & & $\left({ }^{\circ} \mathrm{C}\right)$ & $(\%)$ \\
\hline 0 & 41.0 & 37.0 & 60 & 41.0 & 39.0 & 42 \\
\hline 10 & 45.5 & 38.5 & 60 & 42.0 & 40.0 & 41 \\
\hline 20 & 48.0 & 40.5 & 55 & 44.0 & 40.5 & 41 \\
\hline 30 & 50.0 & 42.5 & 55 & 44.5 & 41.0 & 41 \\
\hline
\end{tabular}

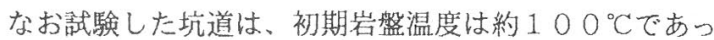
たが、開さく後約 2 年経過しており、その間約 $200 \mathrm{~m}^{3} /$ 分の通気量を流し続けていた。

この結果を見ると、吹付け後は吹付前に比べて、岩盤表 面温度は $3 \sim 5^{\circ} \mathrm{C}$ り、気流の温度上昇は $30 \mathrm{~m}$ 間で、 $3.5{ }^{\circ} \mathrm{C}$ 小さなっている。

通気計算では、坑道の気流温度をある温度まで下げるの に要する時間が、断熱材を吹付けした場合、大幅に短縮さ れることがわかっており、坑道開さく後、速かに吹付を奏 施することにより、もっと大きな効果が期待出来るため現 在開削を進めている信莀銿(岩盤温度 $100^{\circ} \mathrm{C}$ 以上)の入気 坑道に施工する。

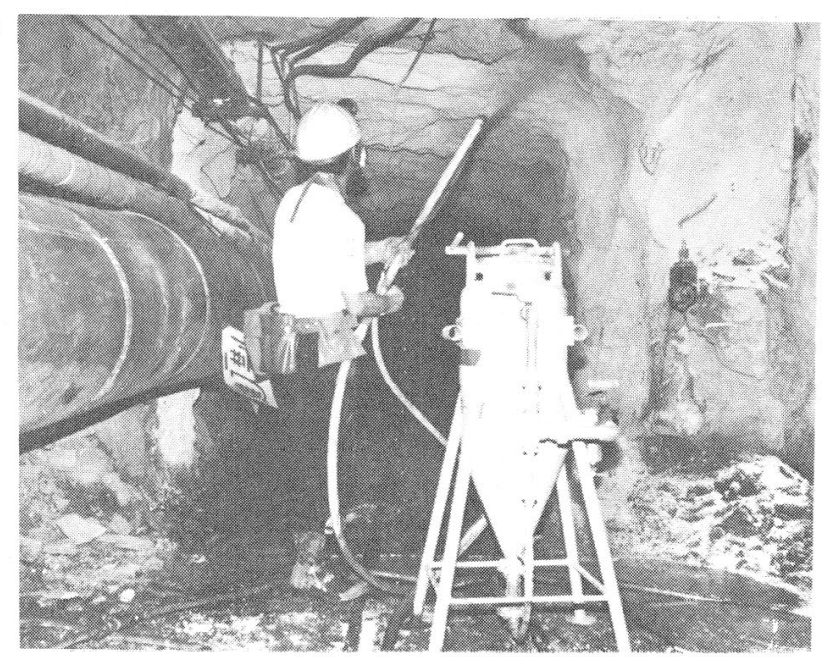

（写真）断熱材吹付施工 
3-3-4.主要通気計西

当山では、主として中央入気、為辺排気の対隅式通気系 統となっており、開発が周辺部に移行するに連九、入気系 統からの距離も長くなり、また近阥の銥休からの排気が入 父に混じるなどの慗害が生じている。

最終的には、通気による坑道冷却が最善であり、独立し た通気係統を確保するための坑道開さくを最優先している

開発を進めている信浱銿の通気については

(1) 独立した通気系統とする。

(2) 鉱体入口での入気温度を $28^{\circ} \mathrm{C}$ 以下にする。

（3）岩盤温度の低い簡所に入気立坑を開さくする。

(4) 既存の排気孔に、入気が短絡しないようにする。

（5）鉱休の末端に、排気立坑を開さくする。

の考えのもとに、入排気立坑位置を選定し、通気計算を行 った結果 $8,000 \mathrm{~m}^{3} /$ 分の通気量を可能とする坑道が必 要とされ、それに沿った開さくを進めている。

以下に通気計算の入出力項目及び通気モデルを示す。

\begin{tabular}{|c|c|}
\hline 入力の項目 & 出力の項目 \\
\hline 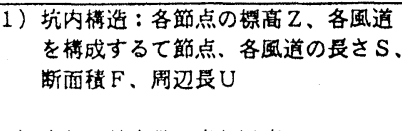 & 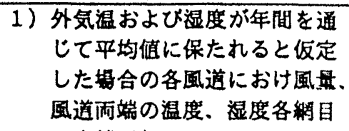 \\
\hline 2）岩桖の慗定数、岩整温度 & の自然通気瓜 \\
\hline $\begin{array}{l}\text { 3）各風道に対して：開削後の経通時間 } \\
\text { 丸九率、摩擦䋆数、経時低数 }\end{array}$ & \\
\hline 4) ファン特性 & \\
\hline 5）坑外気温および湿度の年間平均値 & \\
\hline
\end{tabular}

第 6 表 坑内通気設計システムの入出力項目

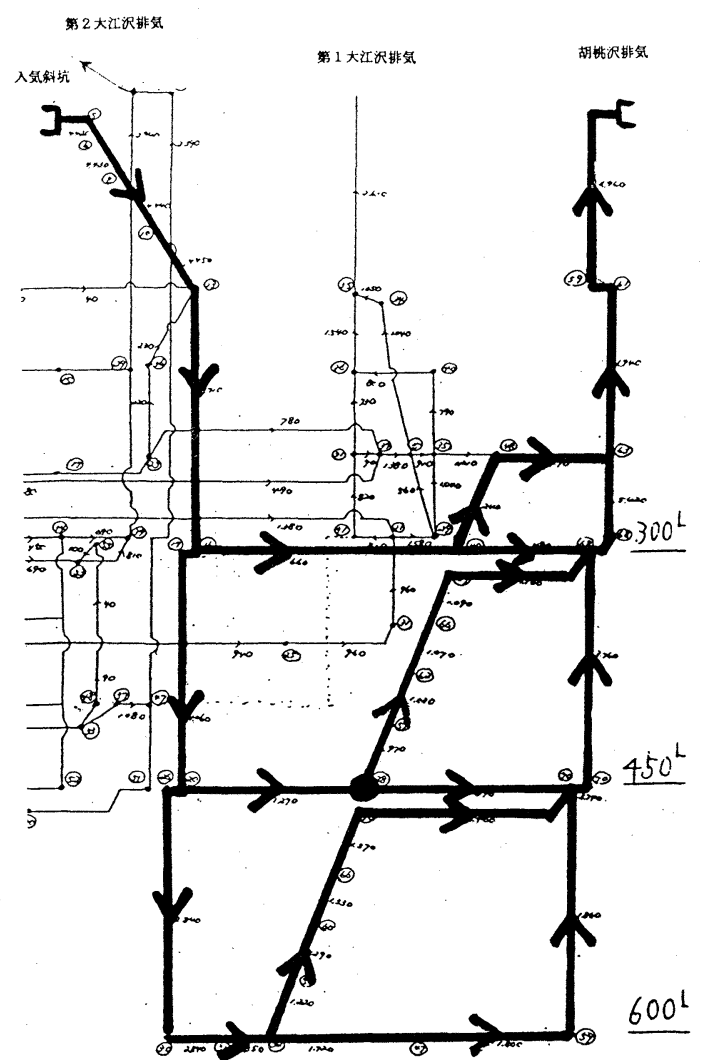

第5図通気計算（将来モデル）
$3-4$. 通気管理

常時、坑内の通気状況を把握するとともに、異常に対し て、迅速な対応を行うため、坑外事務所に通気監視システ ムを設置した。

これは、坑道の主要箅所に設置したセンサーで感知する 温度、湿度、風速等を現場にある子局に表示すると同時に 専用信号線を介して、順次坑外の親局へデータを送り、 コンピュータで監視するものである。また同一信号線を用 いて、坑外から制御を行うことも出来る。

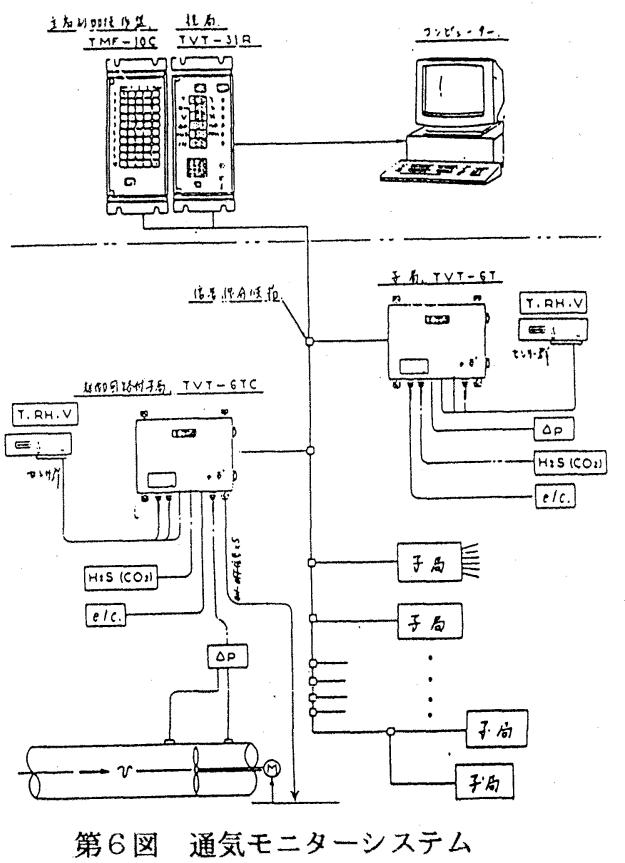

管理、測定及び制御項目については、当面

（イ）リアルタイムの温度、湿度、風速 (風量)、入水 温、主搨差圧をコンピュータ画面に表示する。

（ロ）異常值設定により、整報により巽常簡所を知らせ る。

（ハ）モード設定により、主扇の運転を自動制御する。

（二）湘定結果を、自動プリントアウトする。

以上の事項を行わせるが、将来、ガスの測定及び翼常警 報、局䎑その他の制御等も出来るシステムとなっている。

\section{4.おわりに}

現在の技術では、高温岩盤の開さくは、1 $60{ }^{\circ} \mathrm{C}$ 程度ま では可能であると考えているが、今まで述べた様々な問題 点を克服し、計画通りの環境改善を推進して行く事により 初めて、円滑な操業が出来るものである。

また実行途中においても、新たな問題が生じて来るであ ろうが、現場に適応したきめ細かな対処をしていく所存で ある。 